\title{
Coexistence without conflict, the recovery of Ireland's endangered wild grey partridge Perdix perdix
}

\author{
Kieran Buckley ${ }^{1} \cdot$ Conor O. Gorman ${ }^{2} \cdot$ Michael Martyn $^{2} \cdot$ Brendan Kavanagh $^{3} \cdot$ Alex Copland $^{4} \cdot$ Barry J. McMahon ${ }^{5}$
}

Received: 15 June 2020 / Revised: 7 February 2021 / Accepted: 10 February 2021 / Published online: 27 May 2021

(C) The Author(s) 2021

\begin{abstract}
By 1995, Ireland's wild grey partridge (Perdix perdix) was extinct nationally as a breeding species on farmland. The two populations remaining were confined to Ireland's industrial cutaway peat bogs. One of these populations was deemed viable. In 1996, the National Parks and Wildlife Service of Ireland and the Irish Grey Partridge Conservation Trust established a conservation project to prevent the extirpation of this population. In this paper, we explore the impact of each management factor on two key demographic response variables: chick survival rates and the number of breeding pairs. The numbers of linear metres of nesting strips had the most significantly positive effect on spring pairs, followed by the total number of supplementary food hoppers and the total hectares of brood-rearing and over-winter cover. Counterintuitively, encounters with Hen Harriers (Circus cyaneus) did not negatively affect chick survival or the number of spring pairs. While we cannot rule out the contribution of each explanatory variable, none had a statistically significant effect on chick survival, suggesting there may be locally confounding factors that our model could not capture. The weather conditions during the peak hatching period had a significant influence on chick survival, with the average maximum temperature observed in June having the strongest positive association with an increase of $1{ }^{\circ} \mathrm{C}$ in the average maximum temperature in June associated with an increase in chick survival of $9.4 \%$ on average. Conversely, for every additional $1 \mathrm{~mm}$ of rain in June, there was a $0.23 \%$ drop in chick survival on average.
\end{abstract}

Keywords Chick survival $\cdot$ Cutaway bog $\cdot$ Recovery $\cdot$ Distribution edge

\section{Introduction}

Many European breeding bird populations are in decline (Inger et al. 2015). One of the primary drivers of this decline has been land-use change and agriculture (Donald et al. 2001; Butler et al. 2010). The majority of red-listed breeding birds in

This article is part of the Topical Collection on Road Ecology Guest Editor: Marcello D'Amico

Kieran Buckley

Kieran.buckley@housing.gov.ie

1 National Parks and Wildlife Service, Department of Housing, Local Government and Heritage, Kildare Town, County Kildare, Ireland

2 Irish Grey Partridge Conservation Trust, Kilbeggan, Co. Westmeath, Ireland

3 Royal College of Surgeons in Ireland, Dublin 2, Ireland

4 Knockarlow, Clareen, Birr, Co. Offaly, Ireland

5 UCD School of Agriculture \& Food Science, University College Dublin, Belfield, Dublin 4, Ireland
Ireland are associated with agricultural habitats (Colhoun and Cummins 2013), and one of these species is the grey partridge (Perdix perdix). The grey partridge in Ireland is a resident breeding bird (Ussher and Warren 1900; Sharrock 1976; Potts 1980, 1986; Kavanagh 1992; Whilde 1993). The species was widely distributed up to the mid-nineteenth century (Ussher and Warren 1900), with large hunting bags achieved in County Kildare up to the end of the nineteenth century (Potts 1986). Conversely, some of the earliest and most dramatic population declines of the grey partridge in Europe were in Ireland (Potts 1986). This decline was attributed in part to the breakup of many great Irish estates (Potts 1980). The contraction in the national population was severe enough to prompt a temporary withdrawal of all guns in 1918 and statutory protection in 1930 (Humphreys 1937; Kennedy et al. 1954; Potts 1980). Following these measures, an increase was noted from 1933 onwards (Kennedy et al. 1954), although there is no indication as to the actual size of the population (Hearshaw 1996).

While the underlying factors causing the decline of Ireland's wild grey partridge are not fully understood, their 
decline coincided with the end of small cooperative mixed farming practices known in Ireland as Meitheal. These practices were prevalent in Ireland form the eighteenth century through to the adoption of the Common Agricultural Policy (CAP). This factor combined with the increased usage of chemical pesticides and herbicides, beginning in the late 1960s (Hearshaw 1996), and the loss of traditional grassland management through the changes in reseeding and the frequency of new sward establishment (McMahon et al. 2010), precipitated a $95 \%$ reduction in the range of the national population (Huallacháin et al. 2015). By 1995, two populations remained in the non-agricultural landscape of the cutaway peat bogs of Boora, County Offaly and Lullymore, County Kildare (Kavanagh 1992, 1998). However, due to the persistent poaching of the Lullymore population (Hearshaw 1996; Kavanagh 1998) only the Boora population in County Offaly was deemed viable. In 1996, the Irish Grey Partridge Conservation Project was established to prevent the extirpation of this population. The initial focus of the recovery plan was to build a research-led conservation strategy, beginning with a national population survey in 1991 (Kavanagh 1992). This survey was followed by radio-tracking studies exploring the ecology of the species in the cutaway bog (Hearshaw 1996; Kavanagh 1998; O'Gorman 2001), towards a reintroduction methodology on Irish farmland (Kavanagh 2001) and the use of captive breeding as an additional management strategy (Buckley et al. 2012).

Many of these research findings subsequently contributed to a management strategy, which was implemented by the National Parks and Wildlife Service, Ireland (NPWS), and the Irish Grey Partridge Conservation Trust. In 2016, the NPWS took over sole responsibility for the project and are running it to the present day. Another objective of the grey partridge conservation project was the development of an agrienvironmental measure to support a recovery of the species in its more traditional farmland habitat (Copland et al. 2009). Mainstream, state-support for conservation measures was first delivered through Ireland's Department of Agriculture Food and the Marine (DAFM) Agri-Environment Options Scheme (AEOS), followed by the current Green, Low-Carbon, AgriEnvironment Scheme, (GLAS).

Preventing the extinction of the grey partridge in Ireland presented a distinct conservation challenge typical of a remnant population in the extinction vortex. Our paper describes these challenges and explains how they were met. It outlines the conservation strategy for Ireland's wild grey partridge and suggests explanations for the outcomes of the two key demographic response variables: chick survival and the estimated number of spring pairs over the 20 years. It points to the critical importance of agri-environmental measures that are site-specific and scientifically monitored to underpin the long-term resilience of the national population. We also outline a positive outcome for the Hen Harrier (Circus cyaneus) in Ireland, which we hypothesise was a by-product of an ecosystem-led approach for the conservation of wild grey partridge.

\section{Materials and methods}

\section{Conservation efforts and sources of data}

\section{Site description}

The core managed area for the grey partridge is located in West County Offaly in the midlands of Ireland, commonly referred to as the Boora 'group of bogs' latitude $53^{\circ} 13^{\prime} 18^{\prime \prime}$ (north) longitude $7^{\circ} 43^{\prime} 34^{\prime \prime}$ (west). Once peat production ceases, the resulting landscape is termed a cutaway bog (Egan 1995; Farrell and Foss 1999; O'Gorman 2001; Collier and Scott 2008). These areas provided temporary breeding habitats for the grey partridge (Kavanagh 1992; Hearshaw 1996; Kavanagh 1998; O'Gorman 2001; Whilde 1993). However, breeding opportunities for the grey partridge are chronologically limited by rapid habitat successions (Kavanagh 1990; Hearshaw 1996), which result in the dominance of birch (Betula spp.) willow (Salix spp.) woodland and dense swards of juncus (Juncus. sp.). These habitat transitions militate against the survival of the species. Thus, a key part of the management strategy was to create grey partridge habitats to arrest this process.

\section{Habitats and habitat creation}

The total size of the core managed area is $5.35 \mathrm{~km}^{2}$ comprising 275 ha of former cutaway bog converted to improved grassland and 250 ha of a commercially undeveloped cutaway bog. Before the initiation of the grey partridge conservation project, 388 ha of commercial Sitka spruce (Picea sitchensis) forestry surrounding the core managed area was already established (Jancke 2008). To prevent the further transition of the undeveloped cutaway bog to commercial monocultures of grassland and forestry, which are hostile to a species with a preference for open arable farmland with hedgerows (Whilde 1993), this area of land was purchased by the NPWS specifically for habitat creation. The process of succession on the cutaway bog was arrested by creating a patchwork of habitats recommended for the grey partridge by the Game and Wildlife Conservation Trust (Anon 1992). These habitats were modified by iterations to suit the local conditions. The nesting habitat consisted of a grass mix of Cocksfoot (Dactylis glomerata), Timothy (Phleum pratense) and Red Fescue (Festuca rubra) which was created in 4-metre-wide linear strips. Due to the uneven nature of the underlying soils dominated by peat, the establishment of conservation headlands (Sotherton 1991) was not possible. Thus, it was necessary to 
create habitats with a dual function of providing brood-rearing and over-winter cover. Adjacent to the nesting strips, 4-metrewide linear brood-rearing/over-wintering habitats consisted of a mixture of kale (Brassica oleracea), linseed (Linum usitatissimum), chicory (Cichorium intybus), lucerne (Medicago sativa) and barley (Hordeum vulgar). In the areas where habitat linearity was not possible, 0.5-2 ha blocks of linseed kale mixes and spring barley were sown to exploit all available areas for habitat creation.

\section{Predator control}

From 1996-2016, a continuous programme of systematic predator control took place in the core managed area during the period when grey partridge eggs and broods of chicks were considered at risk of predation by a range of mammalian and avian predators.

The objective of predator control was to reduce predation losses, not to eliminate or exert a general population control on predators (Tapper et al. 1996). These predators were humanely dispatched by trained wild grey partridge keepers using legally sanctioned techniques. Local populations of mink (Neovison vison), brown rats (Rattus norvegicus), and Irish stoats (Mustela erminea hibernica) were controlled by a network of strategically placed Fenn mark 4's and 6's spring traps. The judicious use of rodenticide also controlled brown rats. Local populations of hooded crow (Corvus cornix), magpie (Pica pica) and rooks (Corvus frugilegus) were controlled using multi-catch ladder traps and Larsen traps, and by shooting during the grey partridge nesting season. The principal method used to control feral cats (Felis catus) and red foxes (Vulpes vulpes) was live trapping and lamping with a highpowered rifle at night. To reduce the levels of adult mortality outside of the breeding season, the control of both predatory mammals took place in every month of the year.

\section{Translocations and augmentation of wild grey partridge}

There is compelling evidence that the release of captive-bred hand-reared game-farmed grey partridges is an ineffective conservation strategy due to low post-release survival and reduced breeding success compared to their wild counterparts (Meriggi et al. 2004; Parish and Sotherthon 2007; Buner and Schaub 2008; Buner et al. 2011; Buckley et al. 2012; Rymešová et al. 2013; Homberger et al. 2014). Therefore, the release of commercially reared game-farmed grey partridge, although widely available, was not considered a management option. Thus, only grey partridge with a wild provenance and birds from the local wild population were used in the captive breeding programme to augment the population. Details of the captive breeding programme in Boora are described in Buckley et al. (2012).

\section{Data collection}

\section{Hen Harrier (Circus cyaneus) encounters}

Hen Harriers prey on grey partridge adults throughout the year and their juveniles during the breeding season (Bro et al. 2006); this was also observed on the study site (K. Buckley, R. Archibald pers. obs.; O'Gorman 2001). The project gamekeepers logged random encounters with Hen Harriers in the core managed area on a granularity of days throughout the 20 years. We also examined records over a similar period held by amateur and professional ornithologists from the midlands bird group (S Heery pers com.)

To explore for any statistically significant relationships between the frequency of encounters and its effect on grey partridge chick survival rates (CSRs), and the number of breeding pairs recorded in the following spring, we thus extracted the relevant details from 1996 to 2016. To avoid duplication, one record per day (either gamekeeper or ornithologist) was extracted from the logged records. All other encounters with Hen Harriers inside the core managed area were excluded from the total counts. An encounter is defined as a Hen Harrier observed flying or hovering a short distance above the ground or quartering a short distance above the ground searching for prey or trying to flush prey out of cover.

\section{Population monitoring}

\section{Source data for the estimated autumn populations and spring pair indices}

Due to the mixed nature of the vegetation cover and the soft texture of the peaty soils, it was not possible to survey the entire core managed area by using the standard survey technique, e.g. Potts (1980, 1986), Jenkins (1961) and Green (1984). Initially, autumn and spring surveys were conducted on foot using teams of men with hunting dogs covering predetermined areas. Major autumn surveys were carried out between the third week in September and the middle of October each year. However, no details of age or sex in the autumn coveys could be accurately determined by this method (O’Gorman 2001). Moreover, in two autumn population surveys, radio-tracked coveys, although present in the core managed area, were not located by teams of hunters with dogs during these surveys. Consequently, these survey methods were abandoned in the latter half of the 1990s.

Spring surveys were carried out at dawn and dusk from observational vantage points from the second week in March and completed by the second week in April. From 2004, supplementary food hoppers were also inspected for signs (droppings) of the presence of a territorial pair under the assumption that it was unlikely that more than one pair would nest within $50 \mathrm{~m}^{2}$ of a hopper (Potts 2012). The autumn population pre-release and the 
number of spring pairs are an index of the population only. These surveys were carried out by the project staff who were assisted by the local farmers, workers from Bord na Móna, professional and amateur ornithologists and members of local hunting clubs.

To distinguish between both groups (wild and wild-released), birds from the captive breeding programme (including the birds used to augment the population) were colour-legringed before release Buckley et al. (2012).

Thus, birds in autumn coveys without leg rings were presumed to have bred in the wild. The time window used to estimate the minimum autumn population pre-release and the number of spring pairs remained the same from the outset of the counts in 1996.

\section{Source data for chick survival rates}

CSR is calculated as the proportion of hatched chicks surviving to six weeks (Potts and Aebischer 1995) in a population. CSR can be reliably estimated from the geometric mean brood size, provided the mean brood at hatching is taken into account. We used British data for analysis in this study, as described by Potts (2012), and the sample sizes are a minimum of 2 (Aebischer and Reitz 2000). This method has been validated and verified by four radio-tracking field studies (Green 1984; Rands 1986a; Aebischer and Reitz 2000; Browne et al. 2006; cited in Potts 2012). Juvenile birds were aged using the indices from Potts (1986). From the beginning of the last week in August to the end of the second week in September, the number of juveniles observed and recorded with parent birds was extracted from logged records. To minimise duplication, observations and reports of autumn coveys containing young and old before or after these dates were excluded from the analysis of the CSR. For each year, the number of identified broods and their associated brood size was recorded and used to calculate the geometric mean of the brood size. The CSR for each year was obtained from the corresponding geometric mean using the methodology described by Aebischer and Reitz (2000). Throughout the 20 years, the dates of the first hatches of chicks observed in the wild were also recorded. No data on the autumn population was collected in 2007.

\section{Weather}

The most relevant weather data for CSR was considered to be temperature and precipitation in June (Green 1984; Potts 1986; Rosin et al. 2010). Thus, data were analysed to examine relationships between weather conditions and the CSR in each year. We considered records for May, June and July, from 1996 to 2016 . The weather variables considered for any given month were the mean air temperature, the maximum air temperature, the minimum air temperature, the average maximum temperature (maximum temperature averaged for a given month), the average minimum temperature, the minimum grass temperature, the average wind speed, the precipitation amount, the highest gust and the duration of sunshine and the number of rainy days (defined as a day where the amount of rain exceeded $0.2 \mathrm{~mm}$ ). Information on the precipitation was extracted from records at the $\mathrm{BnM}$ weather station at Blackwater Works, Shannonbridge, County Offaly, Ireland, Latitude $53.162^{\circ} \mathrm{N}$, Longitude $8.227^{\circ} \mathrm{W}$. All other details of weather conditions were obtained from the Irish Metrological Service (Met Éireann) weather station at Casement Aerodrome at Baldonnel, County Dublin, Ireland. $53.303^{\circ} \mathrm{N}, 6.450^{\circ} \mathrm{W}$

\section{Data processing methods}

For each year, the geometric mean and the variation in brood size was calculated using the geometric standard deviation factor (GSDF; Kirkwood 1979) to obtain confidence intervals for the geometric means of the population. The upper and lower confidence bounds are obtained by multiplying the sample geometric mean by the GSDF, and its reciprocal, respectively. The number of spring pairs is used as an index of the year-on-year population and to assess whether the management measures implemented each year, as well as the changes in the management effort year-on-year, both in terms of the actual level and percentage change, may have a lag effect on the number of spring pairs observed the following year. The impact of the predators, namely foxes and Hen Harriers, on the number of spring pairs was also considered.

Buckley et al. (2017) and Heery (2018) have shown that the number of Hen Harrier's encounters over the 20 years varied quarter by quarter, with an increase in the number sighted in the first and fourth quarters of the year. Thus, the total numbers of Hen Harriers encountered each year may influence the number of spring pairs the following year. Therefore, we specifically assessed the relationship between the number of spring pairs in a given year and the number of Hen Harriers encountered in the previous autumn/winter season.

\section{Statistical models of CSRs}

To determine the outcomes, we explored the relationships between CSR and each of the predator management, habitat management, provision of supplementary food hoppers, encounters with Hen Harriers and the weather variables by fitting univariate linear regression models with CSR as the response variable. We also examined categorised versions of the habitat management variables to reflect different levels of management efforts. All models were fitted in R (R Core Team 2017) and were compared based on the modeladjusted R squared value and the $P$ value associated with each explanatory variable tested. Any $P$ value of less than 0.05 was 
considered to be an indication of a statistically significant association between the associated explanatory variable and CSR.

Note that the absence of a statistically significant association between CSR and the explanatory variables ( $P$ value over 0.05 ) only indicates that there is not enough evidence in the data to support such an association rather than providing evidence that no such association exists. With a single record for each year of the project, corresponding to the CSR and associated variables values for each year, it was not possible to consider the effect of multiple variables in a single multivariable linear regression model.

To determine the outcomes of management, we thus explored the relationships between spring pairs and each of the predator control and habitat management variables by fitting univariate linear regression models to the number of spring pairs in the following year, as the response variable. A $P$ value of less than 0.05 was considered to be an indication of a statistically significant association between the associated explanatory variable and spring pairs. Using the variables which were found to show a significant association with spring pairs, we used a stepwise selection algorithm based on the Akaike Information Criterion to consider the effect of multiple variables in a single multivariable linear regression model. With a single record for each year of the project, we were only able to consider a limited number of explanatory variables for inclusion in the final model, and as such, were not able to control for multiple confounding effects that may be present in the data.

\section{Results}

\section{CSR and autumn population indices}

The demographic characteristics of the grey partridge population are presented in Table 1. Throughout this period, the observed geometric mean brood size varied between 4.22 $(\mathrm{GSDF}=1.36, \mathrm{CI}=3.10 ; 5.75)$ in 1995 and $9.58(\mathrm{GSDF}=$ 1.25 , CI $=7.66 ; 11.98)$ in 2014 . The CSR varied in a similar pattern during the same period between $23.61 \%$ (1996) and $68.06 \%$ (2014) with an average CSR over the 20 years of $42.82 \%$. In parallel, the minimum estimated autumn population (pre-released) averaged $167.7( \pm 151.9)$ with numbers below 70 in the first 10 years (average of $36.78 \pm 16.5$ ) and above 70 after 2005 (mean in the following ten years 274.7 \pm 124.9 ). The autumn population pre-released ranged from 42 in 1996 to 248 in 2016, peaking with 524 in 2014 (Table 1). The observed first hatching dates in the wild were consistent throughout the period varying between 27 May (in 2012) and 5 July (in 1996). The majority of the first hatching dates occurred in the first 2 weeks in June.

We found no evidence of a relationship between the implemented management practices in terms of the managed
Table 1 Univariate linear regression model of CSRs, which were statistically significant at the $5 \%$ level. The July average temperature was also the maximum observed average temperature over the 3 months. The parameter coefficient (and its standard error, SE) represents the effect on CSR of an increase of 1 standard deviation (SD) of the corresponding weather variable. The maximum average temperature was confounded by the July average temperature as indicated by italics

\begin{tabular}{|c|c|c|c|c|c|c|}
\hline Weather variable & $\begin{array}{l}\text { Mean value } \\
\text { of the variable } \\
\text { (SD) }\end{array}$ & $\begin{array}{l}\text { Parameter } \\
\text { coefficient } \\
(\mathrm{SE})\end{array}$ & $\begin{array}{l}\text { Parameter } \\
95 \% \text { CI }\end{array}$ & $\begin{array}{l}T \\
\text { statistics }\end{array}$ & $\begin{array}{l}P \\
\text { value }\end{array}$ & $\begin{array}{l}\text { Adjusted } \\
R^{2}\end{array}$ \\
\hline $\begin{array}{c}\text { June average maximum } \\
\text { temperature }\left({ }^{\circ} \mathrm{C}\right)\end{array}$ & $18.04(1.07)$ & $9.4(2.71)$ & $3.7 ; 15.1$ & 3.46 & 0.0028 & 0.367 \\
\hline $\begin{array}{l}\text { June precipitation } \\
\text { amount }(\mathrm{mm})\end{array}$ & $66.03(42.62)$ & $-10(2.89)$ & $-16.1 ; 3.93$ & -3.46 & 0.0028 & 0.366 \\
\hline $\begin{array}{l}\text { Maximum of the average } \\
\text { maximum temperature } \\
\left({ }^{\circ} \mathrm{C}\right)\end{array}$ & $19.68(1.37)$ & $8.56(2.92)$ & $2.42 ; 14.7$ & 2.93 & 0.009 & 0.285 \\
\hline $\begin{array}{l}\text { July average maximum } \\
\text { temperature }\left({ }^{\circ} \mathrm{C}\right)\end{array}$ & $19.65(1.38)$ & $8.5(2.93)$ & $2.34 ; 14.7$ & 2.9 & 0.0095 & 0.281 \\
\hline $\begin{array}{l}\text { Mean of the average } \\
\text { maximum temperature } \\
\qquad\left({ }^{\circ} \mathrm{C}\right)\end{array}$ & $17.67(0.76)$ & $7.8(2.98)$ & $1.54 ; 14.1$ & 2.62 & 0.0174 & 0.236 \\
\hline $\begin{array}{l}\text { June average air } \\
\text { temperature }\left({ }^{\circ} \mathrm{C}\right)\end{array}$ & $13.61(0.86)$ & $7.8(2.98)$ & $1.53 ; 14.1$ & 2.62 & 0.0175 & 0.235 \\
\hline $\begin{array}{l}\text { June sunshine duration } \\
\text { (hour) }\end{array}$ & $\begin{array}{l}166.77 \\
(32.95)\end{array}$ & $7.97(3.05)$ & $1.56 ; 14.4$ & 2.61 & 0.0176 & 0.235 \\
\hline $\begin{array}{l}\text { July maximum air } \\
\text { temperature }\left({ }^{\circ} \mathrm{C}\right)\end{array}$ & $24.51(2.52)$ & $8.05(3.16)$ & $1.41 ; 14.7$ & 2.55 & 0.0202 & 0.224 \\
\hline $\begin{array}{l}\text { July average temperature } \\
\qquad\left({ }^{\circ} \mathrm{C}\right)\end{array}$ & $15.41(1.04)$ & $7.72(3.07)$ & $1.27 ; 14.2$ & 2.51 & 0.0216 & 0.219 \\
\hline $\begin{array}{l}\text { Maximum average } \\
\text { temperature }\left({ }^{\circ} \mathrm{C}\right)\end{array}$ & $15.41(1.04)$ & $7.72(3.07)$ & $1.27 ; 14.2$ & 2.51 & 0.0216 & 0.219 \\
\hline $\begin{array}{l}\text { Rain Intensity in June } \\
(\mathrm{mm} / \text { rainy day })\end{array}$ & $3.96(1.65)$ & $-7.43(3.5)$ & $-14.8 ;-0.05$ & -2.12 & 0.0486 & 0.163 \\
\hline
\end{tabular}


habitats, the removal of predators' encounters with Hen Harriers and CSR. There was a limited indication that the increase in the total number of active trap nights might be associated with an increase in CSR $(P$ value $=0.0832)$. However, the lack of any statistically significant association (at the 5\% threshold) between CSR and any of the management measures may be due to the limited amount of data, which would only permit us to detect relatively strong associations.

The average maximum temperature observed in June seems to have the most positive association with CSR (lowest $P$ value $=$ 0.0028 ), with an increase of $1{ }^{\circ} \mathrm{C}$ in the average maximum temperature in June associated with an increase of CSR of $9.4 \%$ on average. However, the average maximum temperature in June explains less than $40 \%$ of the observed variation in CSR over the period (Fig. 1), indicating that there may be other factors we could not account for that could explain the observed fluctuations in CSR over the period. As all the weather variables are highly correlated, it was not possible to disentangle the relative effect of each weather variable on CSR or to control for additional possible confounders, e.g. the number of predators removed or habitat management enhancement. A significantly negative association was found between CSR and the amount of rain in June (mean standardised coefficient of $-10, \mathrm{CI}=-16.1 ;-3.93, P=0.0028$ ), indicating that every additional $1 \mathrm{~mm}$ of rain in June was associated with a $0.23 \%$ drop in CSR on average (or a $10 \%$ drop in CSR for every additional $42 \mathrm{~mm}$ rain in June).

\section{Spring pairs}

The estimated number of spring pairs increased from 12 in 1996 to 129 by 2016, ranging from 6 in 1998 to 187 in 2014. We also found a statistically significant positive correlation between CSR and the numbers of spring pairs the following year (Spearman's correlation coefficient rho = $0.502, P$ value $=0.028)$. Over the 20 years, we found evidence of a statistically significant relationship between each of the implemented management measures and the number of pairs observed the following spring (Table 2). The numbers of linear metres of nesting strips (standardised coefficient: 68.9, CI: 51.6; 86.2, $P$ value $<0.0001$ ) and the number of supplementary food hoppers (standardised coefficient: 63, CI: 46.9; 79.2, $P$ value $<0.0001$ ) had the most significantly positive effect on the numbers of spring pairs in the following year, which explained $78.4 \%$ and $77.6 \%$ of the observed variation in the number of spring pairs respectively. The total hectares of brood-rearing and over-wintering cover provided also have a strong positive association with the number of spring pairs (Table 3) ( $P$ value $<0.0001)$ explaining $76 \%$ of the observed variation. The total number of Hen Harriers encountered in the 3 rd and 4th quarter of a given year indicates a stronger association with spring pairs in the following year $(P$ value $<$ 0.0001 , and $61.9 \%$ explained variance) compared to Hen Harriers encountered in the 4th quarter and the 1 st quarter of the following year ( $P$ value of 0.002 and $51.9 \%$ explained variance). To try to account for the confounding effects of the management measures, we fitted a multiple variable model (Table 4).

The total number of Hen Harriers encountered in the 3rd and 4th quarters was still found to have a statistically significant association with the number of spring pairs ( $P$ value 0.01$)$ when controlling for the total hectares of brood-rearing and over-wintering covers, which is also statistically significant $(P$ value $=0.013$.

In particular, we found that an increase of the total hectares of brood-rearing and over-wintering cover is statistically
Fig. 1 Relationship between June average maximum temperature and CSR. The blue line represents the predicted CSR as fitted by the linear regression model with the 95\% confidence intervals around the predicted regression line indicated by the BLUE band

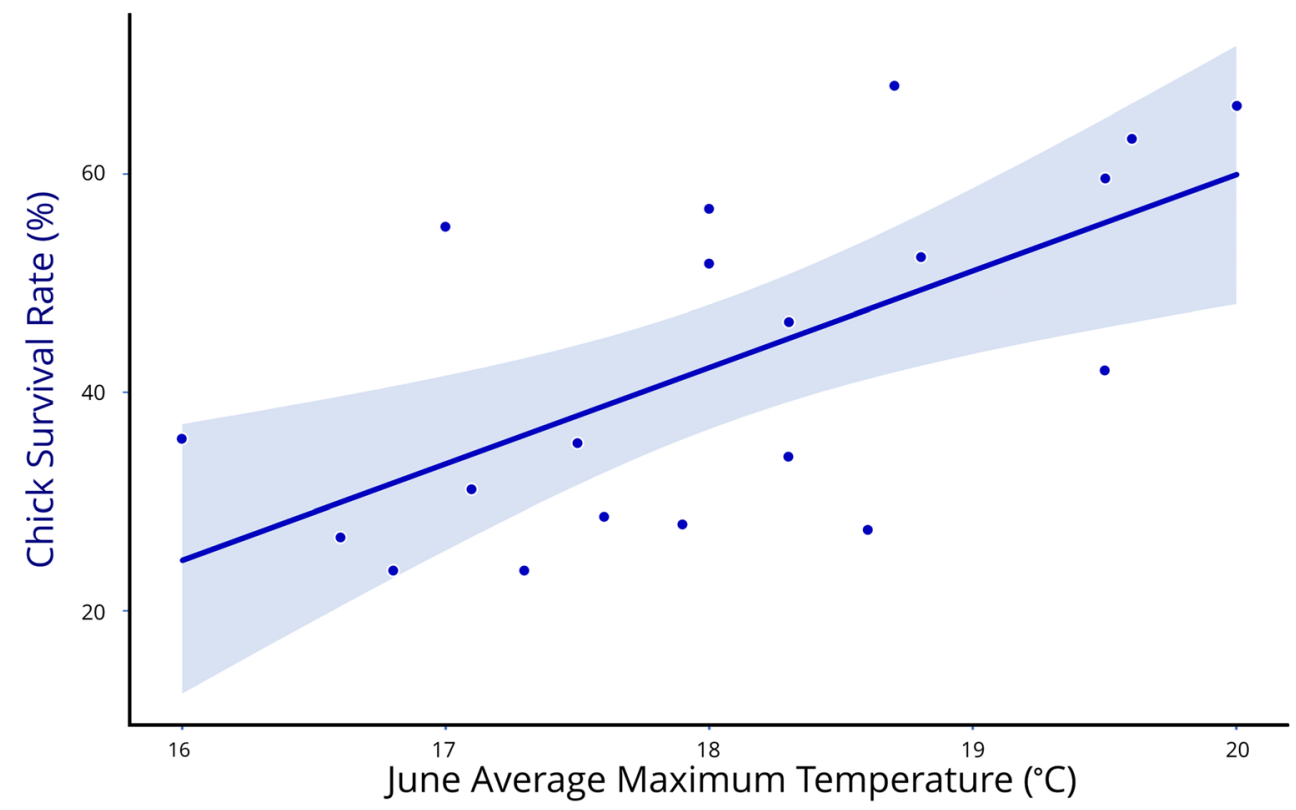


Table 2 Yearly demographic characteristics of the grey partridge population in Boora, Ireland. The yearly number of coveys observed, with the calculated associated geometric mean brood size (lower-upperbound geometric confidence intervals), the number of birds released from the captive breeding programme, chick survival rates of the wild population, spring pairs and the minimum estimated autumn population size pre-release

\begin{tabular}{|c|c|c|c|c|c|c|}
\hline \multirow[t]{2}{*}{ Year } & \multirow[t]{2}{*}{$\begin{array}{l}\text { Number } \\
\text { of } \\
\text { coveys }\end{array}$} & \multirow[t]{2}{*}{$\begin{array}{l}\text { Geometric mean } \\
\text { brood size (lower } \\
\text { bound; upper bound) }\end{array}$} & \multirow[t]{2}{*}{$\begin{array}{l}\text { Number of wild } \\
\text { birds released from } \\
\text { the captive breeding } \\
\text { programme }\end{array}$} & \multirow[t]{2}{*}{$\begin{array}{l}\text { Chick } \\
\text { survival } \\
\text { rates }\end{array}$} & \multicolumn{2}{|c|}{$\begin{array}{l}\text { Index of spring pairs and } \\
\text { minimum autumn population } \\
\text { size pre-releases in the } \\
5.35 \mathrm{~km}^{2} \text { managed area. }\end{array}$} \\
\hline & & & & & $\begin{array}{l}\text { Spring } \\
\text { pairs }\end{array}$ & $\begin{array}{l}\text { Minimum } \\
\text { autumn } \\
\text { population size } \\
\text { pre-released }\end{array}$ \\
\hline 1996 & 6 & $7.157(4.729 ; 10.833)$ & 0 & 46.692 & 12 & 42 \\
\hline 1997 & 9 & $5.827(4.204 ; 8.077)$ & 0 & 35.791 & 14 & 55 \\
\hline 1998 & 5 & $4.224(3.102 ; 5.751)$ & 0 & 23.609 & 6 & 24 \\
\hline 1999 & 4 & $6.402(5.229 ; 7.839)$ & 0 & 23.609 & 7 & 24 \\
\hline 2000 & 4 & $4.899(3.176 ; 7.556)$ & 0 & 28.601 & 8 & 22 \\
\hline 2001 & 3 & $5.769(4.073 ; 8.172)$ & 0 & 35.333 & 8 & 22 \\
\hline 2002 & 5 & $5.232(3.95 ; 6.929)$ & 55 & 31.139 & 14 & 28 \\
\hline 2003 & 6 & $7.83(6.31 ; 9.717)$ & 37 & 52.448 & 17 & 48 \\
\hline 2004 & 7 & $6.598(4.848 ; 8.979)$ & 54 & 42.031 & 24 & 66 \\
\hline 2005 & 7 & $9.041(7.083 ; 11.541)$ & 12 & 63.167 & 27 & 156 \\
\hline 2006 & 8 & $9.379(7.295 ; 12.058)$ & 54 & 66.233 & 29 & 177 \\
\hline 2007 & NA & NA & NA & NA & 25 & NA \\
\hline 2008 & 9 & $4.812(3.983 ; 5.812)$ & 144 & 27.943 & 18 & 98 \\
\hline 2009 & 10 & $4.739(3.168 ; 7.089)$ & 253 & 27.401 & 32 & 220 \\
\hline 2010 & 13 & $9.05(6.962 ; 11.764)$ & 452 & 59.618 & 55 & 302 \\
\hline 2011 & 12 & $8.15(5.777 ; 11.497)$ & 301 & 55.23 & 140 & 391 \\
\hline 2012 & 11 & $4.646(3.486 ; 6.192)$ & 137 & 26.706 & 180 & 193 \\
\hline 2013 & 14 & $8.992(6.096 ; 13.264)$ & 343 & 56.867 & 130 & 335 \\
\hline 2014 & 10 & $9.579(7.662 ; 11.976)$ & 470 & 68.063 & 187 & 524 \\
\hline 2015 & 8 & $7.754(6.411 ; 9.377)$ & 367 & 51.785 & 157 & 378 \\
\hline 2016 & 12 & $5.619(3.979 ; 7.935)$ & 247 & 34.15 & 129 & 248 \\
\hline
\end{tabular}

significantly associated with an increase in the number of spring pairs under constant Hen Harrier numbers. This outcome may indicate that increasing the volume of this habitat improved the survival efficiency of the grey partridge. It is also likely that additional confounding factors exist which were not recorded in the current study. Moreover, due to the size of the data collected, it was not possible to consider all available confounders in the model. The number of foxes culled each year was not found to have a statistically significant effect on the number of spring pairs observed in the following year.

\section{Discussion}

Any study of animal demography relies crucially on an accurate estimation of the demographic parameters such as survival rates or breeding success; however, these methods require a considerable time and effort to implement and belong primarily to the domain of purpose-designed scientific research programmes (Aebischer and Reitz 2000). In such a programme, all animals are assumed to have been counted, and all areas are assumed to have been surveyed; however, this is rarely the case as funding and sheer feasibility allow (Karanth et al. 2003). This was particularly relevant in Ireland's case. Evidence from radio-tracking studies Hearshaw (1996), O'Gorman (2001) showed that the grey partridge on cutaway bogs can move several kilometres per day, and in some instances movements of up to $20 \mathrm{~km}$ during covey breakup and the explorative phase (O'Gorman 2001). Thus, due to the logistical difficulties of counting associated with a cutaway bog, we were unable to calculate brood production rates accurately. Faced with this challenge, we chose the CSRs and the estimated number of breeding pairs as the critical demographic response variables. Under atypical circumstances, this approach was the most statistically accurate way to measure the conservation outcome.

The lack of any statistically significant association (at the 5\% threshold) between CSR and any of the management measures may be due to the limited amount of data, which would only permit us to detect relatively strong associations. Moreover, the absence of a statistically significant association between CSR and the independent variables $(P$ value over 0.05$)$ only indicates 
Table 3 The parameter coefficient (and its standard error, SE) represent the effect of an increase of 1 standard deviation (SD) of the corresponding variable on the number of spring pairs

\begin{tabular}{|c|c|c|c|c|c|c|}
\hline Variable & $\begin{array}{l}\text { Mean value of } \\
\text { the variable (SD) }\end{array}$ & $\begin{array}{l}\text { Parameter } \\
\text { coefficient (SE) }\end{array}$ & $\begin{array}{l}\text { Parameter } \\
95 \% \text { CI }\end{array}$ & $T$ statistics & $P$ value & Adjusted $R^{2}$ \\
\hline $\begin{array}{l}\text { Number of linear metres } \\
\text { of nesting strips }\end{array}$ & $3384.286(4053.663)$ & $68.9(8.24)$ & $51.6 ; 86.2$ & 8.36 & $<0.0001$ & 0.78 \\
\hline $\begin{array}{l}\text { Total hectares of brood-rearing } \\
\text { and over-wintering covers }\end{array}$ & $43.524(39.683)$ & $59(7.53)$ & $43.1 ; 74.8$ & 7.83 & $<0.0001$ & 0.76 \\
\hline Number of supplementary food hoppers & $45.333(55.769)$ & $63(7.7)$ & $46.9 ; 79.2$ & 8.19 & $<0.0001$ & 0.78 \\
\hline $\begin{array}{l}\text { Total annual number of Hen Harriers } \\
\text { sighted in the managed area each year }\end{array}$ & $32.619(34.049)$ & $57.6(7.22)$ & $42.5 ; 72.8$ & 7.98 & $<0.0001$ & 0.77 \\
\hline $\begin{array}{l}\text { Total number of Hen Harriers sighted } \\
\text { in the managed area in the 3rd and } 4 \text { th } \\
\text { quarter of each given year }\end{array}$ & $20.714(22.139)$ & $52.7(9.32)$ & $33.1 ; 72.3$ & 5.65 & $<0.0001$ & 0.62 \\
\hline $\begin{array}{l}\text { Total number of Hen Harriers sighted } \\
\text { in the managed area in the 4th quarter } \\
\text { of a given year and the 1st quarter } \\
\text { of the following year }\end{array}$ & $23.143(26.360)$ & $48.5(10.9)$ & $25.4 ; 71.6$ & 4.44 & 0.0002 & 0.52 \\
\hline
\end{tabular}

that there is not enough evidence in the data to support such an association, rather than providing evidence that no such association exists.

The results of this study are consistent with previously reported work by Reitz (1988), illustrating the strong negative relationship between CSR and the amount of rain experienced by the chicks in the critical 21 days post-hatch. As illustrated in Fig. 2, this critical post-hatching corresponds to the first 2 weeks in June for most years during the study period. Statistical models of CSR have been found in previous studies to be a key determinant of grey partridge population dynamics, explaining most of the fluctuation's year-on-year in the population numbers, e.g. (Blank et al. 1967; Potts and Aebischer 1995; Pépin et al. 2008). While our models explain a strong association between the management variables and the number of spring pairs, they explain less than $40 \%$ of the observed variation in the CSRs over the period Fig. 1. Concerning the factor(s) we were not able to account for, there are a number of possibilities (Figs 3, 4, 5 and 6).

Table 4 Selected multiple variable model showing the parameter coefficient (and its standard error, SE) represents the effect on the number of spring pairs of an increase of 1 standard deviation (SD) of the corresponding variable. The $T$ statistics and $P$ value indicate the strength of the association between the corresponding variable and the

\section{Predation}

Where non-chick-mortality is high, for example, predation levels on eggs in nests are high; grey partridge populations become more vulnerable to declines in chick survival (Potts and Aebischer 1995). Replacement clutches are usually smaller and thus yield fewer chicks (Yeatter 1934; McCabe and Hawkins 1946; Potts 1986; Carroll 1990). However, without reliable estimates of the overall predator populations, the numbers removed cannot be used to establish a threshold of the maximum sustainable numbers of predators permitted. For instance, a large number of predators removed in a given year could indicate either that the predator population that year was significantly high or that the predator management method was particularly useful that year or both. There is evidence that predator control benefits the breeding productivity of grey partridges (Potts 1980, 1986; Tapper et al. 1996).

However, in this study, other factors such as the potentially negative impacts of high densities of rooks, which increased

number of spring pairs. The value of the intercept represents the estimated number of spring pairs when 43.5 ha of brood-rearing and over-wintering cover and about 21 Hen Harriers were encountered in the previous year between July and December

\begin{tabular}{llll}
\hline Variable & $\begin{array}{l}\text { Parameter } \\
\text { coefficient (SE) }\end{array}$ & Parameter 95\% CI & $T$ statistics \\
\hline (Intercept) & $64.263(6.007)$ & $(51.59,76.936)$ & \\
$\begin{array}{l}\text { Total hectares of brood-rearing } \\
\text { and over-wintering covers }\end{array}$ & $31.527(11.381)$ & $(7.516,55.539)$ & 2.77 \\
$\begin{array}{l}\text { Total number of Hen Harriers sighted } \\
\quad \text { in the managed area in the 3rd and 4th } \\
\quad \text { quarter of a given year }\end{array}$ & $32.136(11.077)$ & $(8.765,55.506)$ & 2.901 \\
\hline
\end{tabular}


Fig. 2 Relationship between the average precipitation in June and CSR. The blue line represents the predicted CSR as fitted by the linear regression model in Table 2, with the $95 \%$ confidence intervals around the predicted regression line indicated by the BLUE band

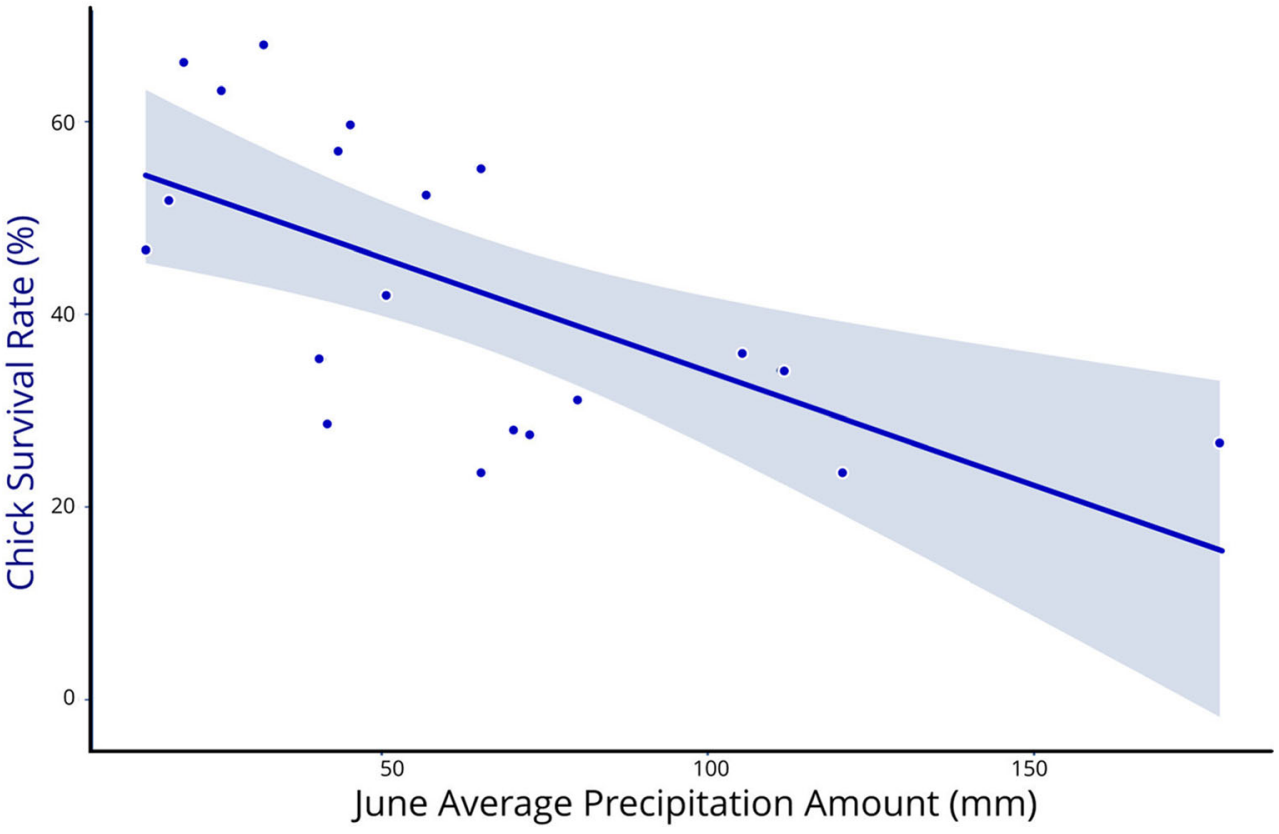

significantly in the core managed area during the peak grey partridge hatching period, may have had a detrimental effect on the CSRs.

Apart from the proclivity of rooks to predate the eggs or chicks of the grey partridge (Anon 1992), rooks are also reservoirs of Syngamus trachea (Morgan and Clapham 1934; Coombs 1978; Potts 1986). S. trachea can cause high mortality in grey partridge chicks (Jenkins 1955; Potts 1986). Thus, a potential mechanism for the transmission of $S$. trachea to grey partridge chicks or juveniles below the age of 6 weeks cannot be discounted.

\section{Mowing and other accidents}

Mowing is one of the two principal causes of nest losses in grey partridge (Westerskov 1949; Potts 1980, 1986; Bro et al. 2004; De Leo et al. 2004; Potts 2012). In this study, the majority of the first hatching dates occurred in the first fortnight in June. By extrapolation, it is plausible that May and June may have been a particularly vulnerable period for incubating grey partridge nesting in improved grassland or foraging at the edge of commercial grassland with their brood of chicks, which was often the case. Both of these months coincide with
Fig. 3 Boxplots of the proportion of yearly Hen Harrier encounters per quarter over 20 years (Data from Buckley et al. 2017)

\section{Proportion of encounters per quarter}

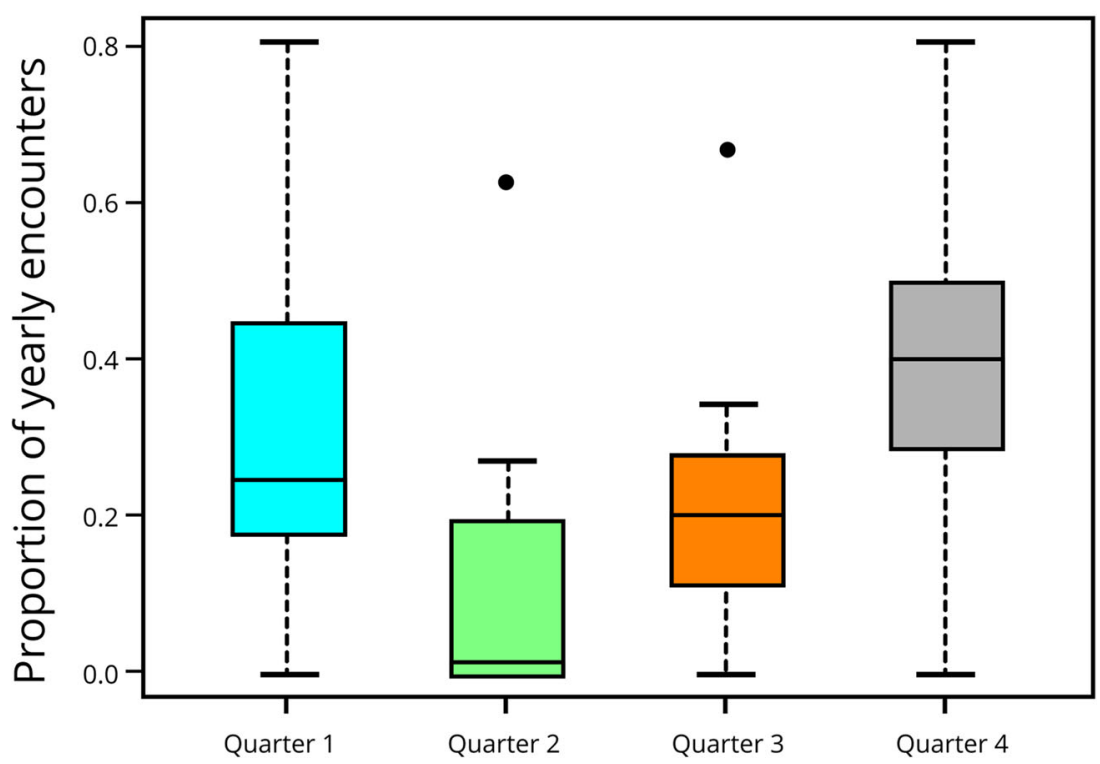


Fig. 4 Annual fluctuations in chick survival rate (solid line) and the index of the minimum estimated autumn population size pre-released (dot-dashed)

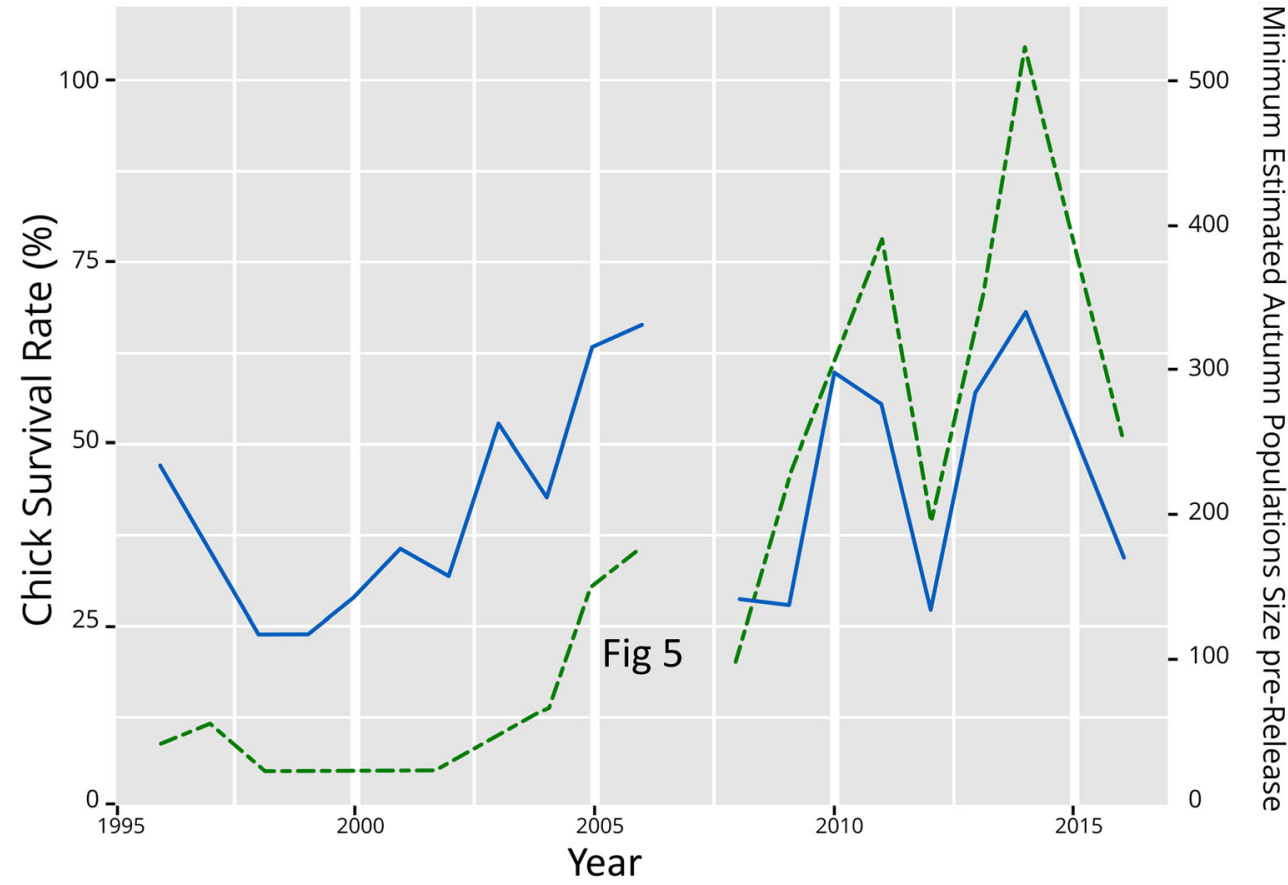

the peak of the silage harvesting (Buckley. K pers. obs. 19962016). In some years 1996, 1998, 1999, 2001, 2002 and 2012, grey partridge nests with clutches of eggs were isolated from mechanical cutting operations or physically removed and placed under incubating female grey partridge in the captive breeding programme. By deduction, there may have been similar incidents of mowing accidents involving the loss of clutches of eggs or entire broods of chicks that we could not account for.

\section{Chick food supplies}

Throughout the 20 years, no pesticides were used, and herbicides were only applied on rare occasions when no other options were available to prevent noxious weed infestation. Thus, synthetic herbicides were unlikely to have been a significant factor directly or indirectly affecting the availability of adequate supplies of grey partridge chick food. Many authors have provided evidence that cold, wet weather during the

Fig. 5 Chick survival rate and the geometric mean brood size per year. The CSR variation is indicated by the solid line, with the average CSR over the period indicated by the dashed line. The bars represent the calculated geometric mean of brood sizes over the number of observed coveys (number indicated in the boxed below each bar), with the associated error bars

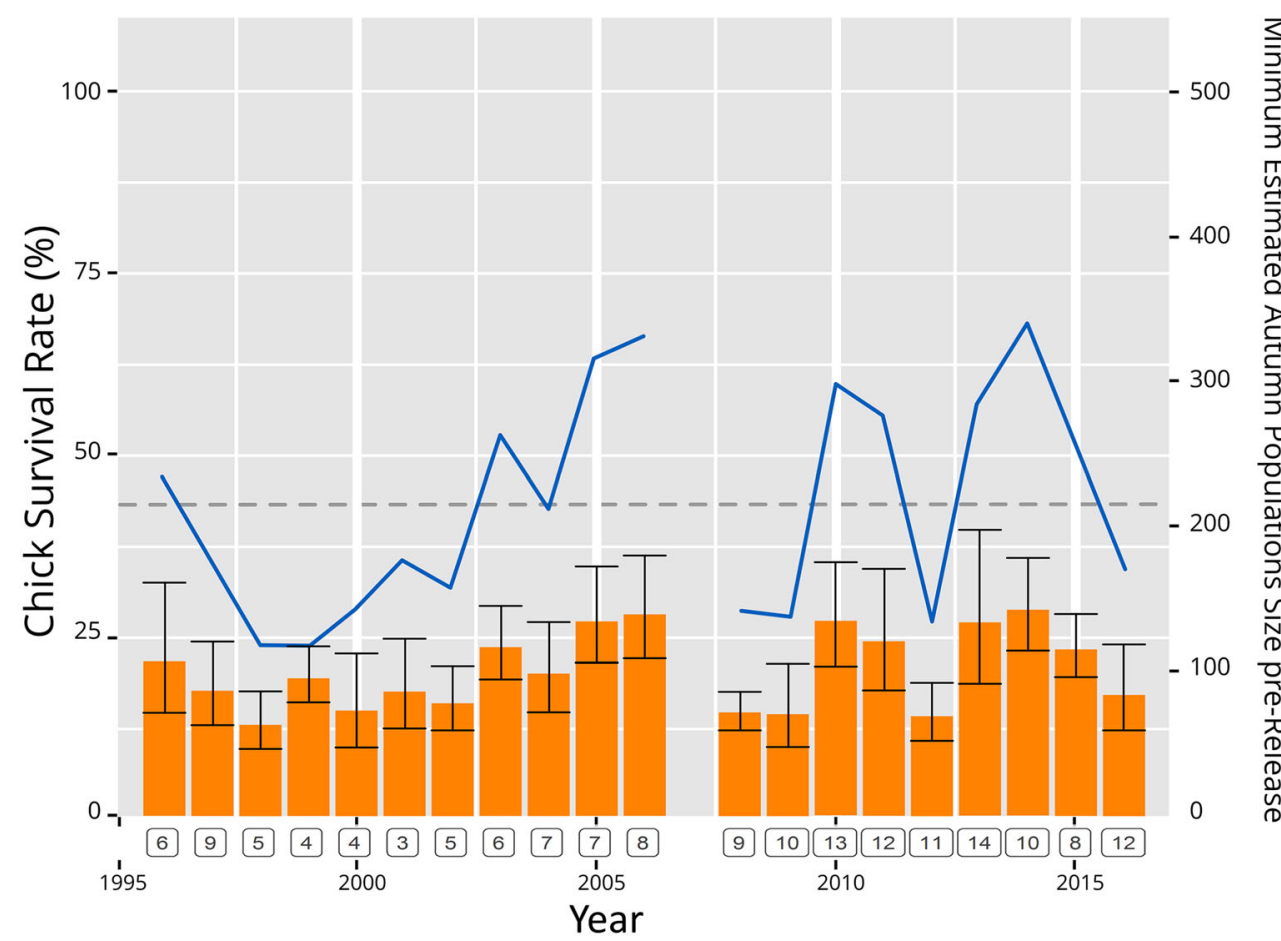


Fig. 6 Encounters with Ring Tail versus Grey Male Hen Harriers 1996-2016 (Data from Buckley et al. 2017)
Hen Harrier encounters - Ring Tail vs Grey Male

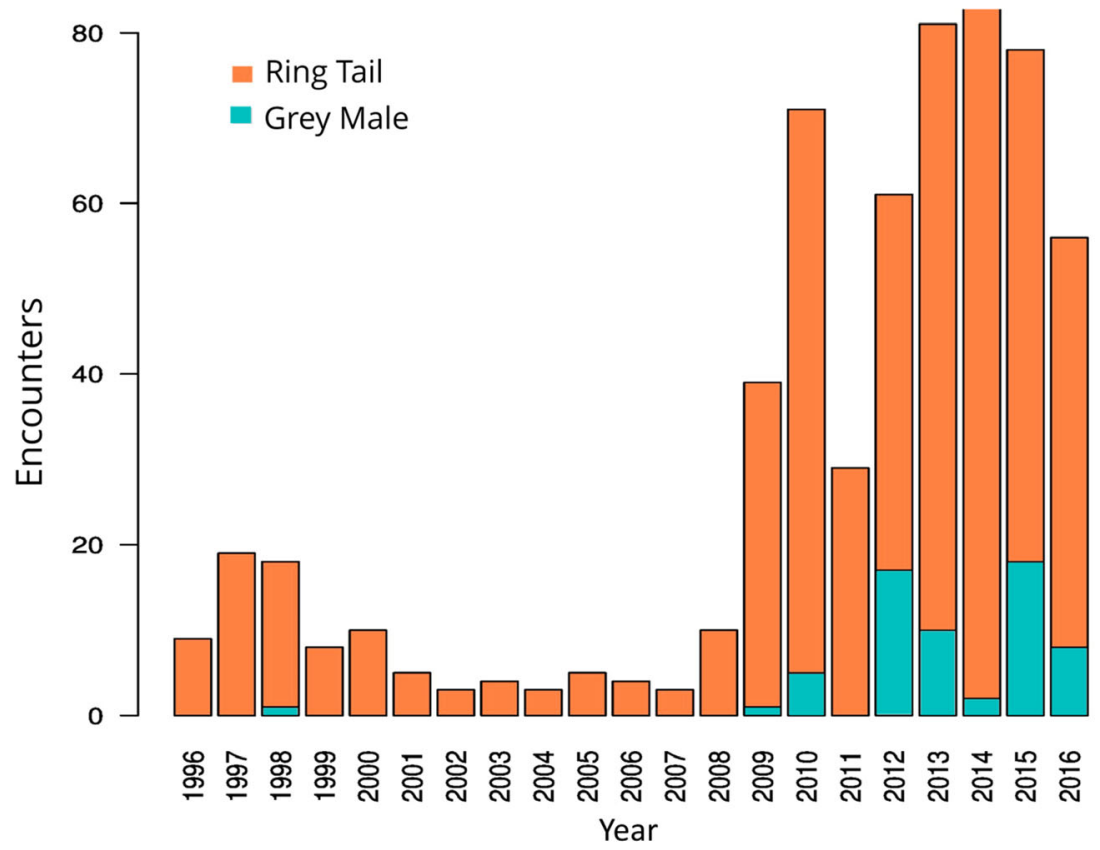

post-hatching period can lead to poor breeding success (Blank and Ash 1962; Reitz 1988; Rands 1985; Dahlgren 1987; Enck 1987; Dahlgren 1990; Panek 1992; Rosin et al. 2010).

Our results are consistent with previously reported work by Reitz (1988), illustrating the strong negative relationship between CSR and the amount of rain experienced by the chicks in the critical 21-day post-hatching. This critical period posthatching corresponded to the first fortnight in June for most years during our study period.

Variability in CSR is thought to be primarily related to the availability of arthropods (Potts 1980; Green 1984; Rands 1985; Potts 1986; Rands 1986a, 1986b). Indeed, Ewald et al. (2015) suggest that in general, if the abundance of a taxon increased with temperature, it declined with precipitation and vice versa. As the weather variables are highly correlated to the CSRs, it would seem plausible that the availability of grey partridge chick food may have been inadequate in the years with wet or cold weather conditions, even though pesticides were never used, and ideal chick-rearing habitat was available. This factor was probably the most likely cause of the poor chick survival that our models could not capture.

\section{The impact of Hen Harriers}

Although no causal relationships were established, Bro et al. (2001) showed that the high overall mortality of healthy female grey partridge in France during the spring and summer points to the harriers, especially Hen Harriers, having a significant impact: the predation rate on adult female grey partridge doubled as the number of marsh and Hen Harriers increased fourfold (cited in Potts 2012). In that context, the impact of Hen Harriers on the population dynamics of grey partridge in this study was a counter-intuitive finding. However, we cannot establish the nature of this relationship or whether it was causal or correlative.

Concerning the CSR over the 20 years, the seasonal patterns suggest that the number of encounters with Hen Harriers peaked in the first and last yearly quartile (Buckley et al. 2017; Heery 2018 ). Outside of this period, the reduction in the rate of encounters between both species was probably driven by the breeding phenology of the Hen Harriers as they left the study area to establish breeding territories in the upland areas of Ireland. These movements coincided with the critical period of the grey partridge breeding season and may have reduced the likelihood of predation encounters. Paradoxically, when the rate of encounters with Hen Harriers increased during the autumn and winter months, it did not negatively affect the estimated number of pairs of grey partridge in the following spring.

Craighead and Craighead (1956) suggest that during the autumn and the winter, raptors in the weight range of Hen Harriers required an average of $15.85 \%$ of their body weight per day. During these particular months, the abundance of alternative prey resources in the core managed area may have facilitated that requirement.

Over a period of 8 years 2008-2016, an estimated 7789 passerines were recorded along three line transects in the grey partridge habitats during the winter months in the study area (K. Buckley unpubl. data). Passerines, whether large or small, constituted the most significant proportion of the Hen 
Harriers' diet in Ireland (O’Donoghue 2010). Preston (1990) suggests that raptor preferences for different habitats probably reflected foraging activity, i.e. the function of prey abundance and its vulnerability to capture. Also, the prey base for Hen Harriers in Boora was augmented by a high density of small mammals and lagomorphs, which featured prominently in the diet of Irish Stoats trapped in Boora (Buckley et al. 2015). When taken together, the abundance of passerines, small mammals and lagomorphs, probably created optimal foraging conditions, in which predation on grey partridge by Hen Harriers may have been incidental. Proportionally, the availability of over-winter cover habitats and grass nesting strips, in a relatively open landscape where Hen Harriers tend to hunt (Watson 1977), was significantly higher in Boora than it was in the French study sites located on an intensive farmland in central-northern France (Bro et al. 2006). These may have been the reasons for the relatively benign coexistence of both species in this study. However, the results from a univariate model only measure the associations between the two variables and do not take into account the effect of any other confounding factors.

It is somewhat of a paradox that the recovery of this native game bird was not antagonistic to the conservation of a species known to prey on it. In some respects, this outcome was not evident until it was examined in retrospect. Over the 20 years, 686 encounters with Hen Harriers were recorded, of which an estimated $9.3 \%$ were adult males (Buckley et al. 2017). It is not unlikely that the remaining $90.07 \%$ comprised a significant number of juvenile birds. The juvenile survival rate of Hen Harriers in Ireland is approximately one in four (O'Donoghue 2010). The proportion of the encounters over the 20 years was probably young birds and thus inexperienced hunters. In that context, the grey partridge conservation area in Boora may be a nationally important site for the Hen Harrier because it is a prey-rich environment located at a geographically important intersection during their critical post-fledging phase. It was somewhat serendipitous that habitat measures designed for the conservation of the grey partridge delivered a positive but unexpected outcome for the Hen Harrier, a European Annex 1 species. Nonetheless, it is an exemplar of a cost-effective outcome for nature conservation and a particularly strong case for the continued support of Ireland's grey partridge GLAS agri-environmental measure.

\section{The realpolitik of nature conservation}

It was not until the late 1980s that the critical status of Ireland's wild grey partridge was raised by an NPWS Officer advocating for their conservation (see Appendix). Up to that point, the decline of the species in Ireland received little attention (Kavanagh 1992). In 1992, Ireland's largest shooting organisation operated a voluntary shooting ban (Crofton 1996). However, their voluntary shooting ban was only applicable voluntarily to their members. While this moratorium was a positive development, it offered no statutory protection, and no legal or moral obligation from a significantly larger body of hunters outside of this organisation to comply. The attestation of this occurred in 1994 at Lullymore when a radio-tracked female in a covey of three was shot close to a favoured feeding spot (Hearshaw 1996). Moreover, two wild grey partridges shot in Lullymore were offered for sale to a nearby village butcher shop (Hearshaw 1996). In effect, one of the two remaining wild populations in Ireland was still been hunted and shot at an average density of $0.00384 \mathrm{birds} / \mathrm{ha}$. Given this precarious position, the NPWS were approached by Ireland's grey partridge conservationists to commence the legal protection of the two wild populations that remained. Consequently, in 1995, Ireland's wild grey partridge was given statutory protection for the second time in their history.

Efforts to prevent the extinction of a national population worked within a framework of conservation life support. Thus, a facultative approach was necessary because stochastic processes are much more important than selection in very small populations (McMahon et al. 2014). Therefore, all methods of propagation, both natural and assisted, had to be considered. In that context, the captive breeding programme has been an essential component of the recovery prescription. Moreover, it presented the opportunity to preserve the genetic composition of the indigenous population and created a reliable source of wild birds for grey partridge conservation projects outside of Boora. However, by itself, it is not a long-term solution (Buckley et al. 2012). It should be phased out as soon as practicable because environmental stability through future agri-environmental schemes is a fundamental requirement to address the intensification of agricultural practices that are at the root cause of the decline.

The recovery of the grey partridge in Ireland is all the more striking because the outcome was accomplished in a landscape that was the anthesis of a farmland ecosystem. In their most recent Bird Atlas (Balmer et al. 2013), the British Trust for Ornithology (BTO) appeared to indicate that the recovery in Ireland is due to "releases"-seriously misquoting Potts (2012) (G.R. Potts, pers. comm). Clearly, with an average CSR of $42.82 \%$, such an assertion was made in error. The survival of the grey partridge as a naturally occurring species in Ireland is also important in a European context because Ireland represents the Western edge of their geographical range. However, for a real conservation success, the ongoing management of the core Boora population is critical because this project is at the nexus of a national recovery.

Experience with the current GLAS grey partridge agrienvironmental measure in Ireland has shown that maximising farmer participation is, first and foremost, linked to a financial incentive to participate. Given the variability of the Irish landscape, the long-term resilience of a recovery is intrinsically linked to agri-environmental measures that are commensurate with the 
challenge. Moreover, scientists from the UK Game and Wildlife Conservation Trust suggest that the existence of science-based prescriptions for recovery does not mean that enough farmers will embrace the opportunity to participate unless there is professional advice to accompany the measure (Sotherton et al. 2014). Ireland shares a similar experience, and we also conclude that one-to-one professional advice is a fundamentally important part of the national recovery prescription.

Weather conditions in Ireland create an even more significant challenge to a national recovery because chick mortality rates are highest where (or when) the post-hatching weather during peak hatch is cool and damp (Potts and Aebischer 1995). Indeed, stochastic fluctuations in a small population frequently lead to local extinction (Newton 1993). The fact that predator control in Ireland is carried out on a recreational basis also brings into focus the necessity to deliver habitats at the appropriate landscape scale to reduce the impact of nest predation, which Potts $(1980,1986)$ suggests dramatically influences the size of grey partridge populations. Thus, the inclusion of predator control as a complementary requirement in future agri-environmental measures for the grey partridge should also be considered an additional option.

\section{Conclusions}

Across Europe, the evidence suggests that shooting is the critical motivation driving the conservation actions for the grey partridge (Bro et al. 2001; Aebischer and Ewald 2010; Ewald et al. 2012; Potts 2012). Given the strong historical association with wild partridge shooting across Europe, such a link is unsurprising. However, Ireland represents a case that appears to run contrary to this assertion. Unlike other European countries, the primary driver of conservation actions for the grey partridge in Ireland was not shooting interests. It was led by a small number of scientists working together with Ireland's shooting community to restore the fortunes of a species they most likely will never hunt.

Over the past 40 years, wild grey partridges have experienced a $95 \%$ reduction in their range across the island of Ireland: the most significant contraction in the range of any resident bird species associated with lowland farmland habitats. Moreover, by the beginning of the twenty-first century, with a national population of 22 birds, the species was on the verge of extinction. It has also undergone the steepest declines of all European farmland birds (Keller et al. 2020), with 94\% of the European population (excluding Eastern European strongholds) been lost (Keller et al. 2020). When taken together, this outcome manifests the damage to the farmland ecosystem caused by an inexorable drive to increase food production. Nonetheless, there are examples of how the demands of food production in the twenty-first century can co-exist within a matrix of farmland that is biologically diverse. One of the best examples of this is the Sussex Study Area in the UK (Potts 2012). Backed up by 52 years of science (Aebischer and Ewald 2010), there are valuable lessons from the Sussex Study Area that can be applied to the recovery of the species in Ireland as we plan the next phase of a national conservation strategy. The EU Biodiversity Strategy for 2030, launched by the European Commission on 20 May 2020, proposes ambitious EU actions and commitments to halt biodiversity loss in Europe. The loss of biodiversity is a pan European problem that is particularly pronounced in the denudation of farmland birds like the grey partridge, arguably the most conspicuous indicator of a biologically diverse farmland. Indeed, the species is the barometer by which we measure our attempts to restore a functional farmland ecosystem. Therefore, we must re-double our efforts because we cannot lose another farmland bird, and above all this flagship species.

Successful conservation projects understand and respect the views of groups with different priorities, values and ideas (Brewin et al. 2020). Our experience has shown that this approach cannot be successful if it operates from an abstract position. What is required is professional one-to-one advice and support for the participating farmers and meaningful assistance for Ireland's grey partridge enthusiasts involved in recovery projects. If a national recovery depends on goodwill alone, it is bedded on sand.

In conclusion, without the enthusiasm of conservationists supported by the intervention of Ireland's NPWS, it is almost certain that wild grey partridge would have experienced the same fate as the corn bunting (Emberiza calandra), which is now extinct as a breeding species in Ireland. A salutary lesson of what could have happened to another naturally occurring species if a meaningful intervention was not forthcoming. It is also perhaps an example of the coexistence of what are often regarded as antagonistic species that would not be obvious in any short-term study. This outcome was somewhat serendipitous; however, at a fundamental level, the resources required to create the correct environmental conditions were provided and without them, this lesson may not have been learned.

Supplementary Information The online version contains supplementary material available at https://doi.org/10.1007/s10344-021-01470-w.

Acknowledgements We are all indebted to Mr. Val Swan. His interventions at crucial moments effectively prevented the extinction of the grey partridge as a naturally occurring species on the island of Ireland. We also recognise and thank Paddy J Kelly for his dedication. Many thanks to the Irish Grey Partridge Conservation Trust: Éabhín Byrne, Shane Sweeney, Richard Roche Conleth, and Peader Farrell, John and Damian Walsh, James Dowling, and Ronan Hannigan, all of whom stayed with the challenge of saving the species during a dark and challenging time when an extinction seemed like a distinct possibility. Thanks also to the regional management and staff of the NPWS, both past, and 
present; Jim Moore, Padraig Comerford, Noel Bugler, Colm Malone, Damian Clarke, Maurice Eakin, Ciara Flynn, John Wilson, Emmett Johnson, Patrick Warner, and the late Judit Kelemen. We are very grateful for the support of the Native Species Conservation Committee of Dublin Zoo, particularly Sandra Molloy, their Research and Conservation Coordinator.

We also recognise the role played by the staff of the NPWS Science and Biodiversity Unit, particularly Ciaran O' Keeffe, whose support throughout made it possible to persist. Thanks to David Tierney,Alyn Walsh, and Andy Bleasdale. We wish Padraig O Donnell NPWS, the current Project Manager, and his team every success with their endeavours. Thanks also to Tom Egan, Don O Bolye and Kevin Healy of Bord $\mathrm{Na}$ Mona, and the local farming community, particularly Joseph and Josie Molloy. We recognise the support of Hans Viser, the Biodiversity Officer of Fingal County Council, Co. Dublin. Derek O Brien, and the Regional Game Councils of Offaly, Dublin and Donegal. Thanks also to David Scallan of FACE Europe and Andres Lilimae, Andres Lilimae of the Estonian Hunters Federation. We also acknowledge and thank the Game \& Wildlife Conservation Trust, U.K.; Malcolm Brockless, Nick Sotherthon, Pete Thompson, Francis Buner, and Julie Ewald. A special mention for the late G.R. (Dick) Potts for his invaluable advice and the encouragement to "keep going." And finally, for Janet, Cliona, and Grace Buckley for their patience and forbearance.

Open Access This article is licensed under a Creative Commons Attribution 4.0 International License, which permits use, sharing, adaptation, distribution and reproduction in any medium or format, as long as you give appropriate credit to the original author(s) and the source, provide a link to the Creative Commons licence, and indicate if changes were made. The images or other third party material in this article are included in the article's Creative Commons licence, unless indicated otherwise in a credit line to the material. If material is not included in the article's Creative Commons licence and your intended use is not permitted by statutory regulation or exceeds the permitted use, you will need to obtain permission directly from the copyright holder. To view a copy of this licence, visit http://creativecommons.org/licenses/by/4.0/.

\section{References}

Aebischer NJ, Ewald JA (2010) Grey partridge Perdix perdix in the UK: recovery status, set-aside and shooting. IBIS 152:530-542. https:// doi.org/10.1111/j.1474-919X.2010.01037.x

Aebischer NJ, Ewald JA (2012) The grey partridge in the UK: population status, research, policy and prospects. Anim Biodivers Conserv 35: 353-362

Aebischer NJ, Reitz F (2000) Estimating brood production rate and chick survival rates of grey partridges: an evaluation. Hung Small Game Bull 5:191-211

Anon (1992) Wild partridge management. Game Conservancy Ltd., Fordingbridge

Balmer DE, Gillings S, Caffery BJ, Swann RL, Downie IS, Fuller RJ (2013) Bird Atlas 2007-2011: the breeding and wintering birds of Britain and Ireland. BTO Books, Thetford

Blank TH, Ash JS (1962) Fluctuations in a partridge population. In: LeCren ED, Holdgate MW (eds) The exploitation of natural animal populations. John Wiley \& Sons, New York, pp 118-133

Blank TH, Southwood TRE, Cross DJ (1967) The ecology of the partridge: I. Outline of population processes with particular reference to chick mortality and nest density. J Anim Ecol 36:549-556. https:// doi.org/10.2307/2811

Brewin J, Buner F, Ewald J (2020) Farming with nature - promoting biodiversity across Europe through partridge conservation. The Game and Wildlife Conservation Trust, Fordingbridge
Bro E, Reitz F, Colbert J, Migot P, Massot M (2001) Diganosing the environmental causes of the decline of the grey partridge, (Perdix perdix) survival in France. Ibis 143:120-132. https://doi.org/10. 1111/j.1474-919X.2001.tb04176.x

Bro E, Mayot P, Corda EVE, Reitz F (2004) Impact of habitat management on grey partridge populations: assessing wildlife cover using a multisite BACI experiment. J Appl Ecol 41:846-857. https://doi. org/10.1111/j.0021-8901.2004.00939.x

Bro E, Arroyo B, Migot P (2006) The conflict between grey partridge Perdix perdix hunting and hen harrier (Circus cyaneus) protection in France: a review. Wildl Biol 12:233-247. https://doi.org/10.2981/ 0909-6396(2006)12[233:CBGPPP]2.0.CO;2

Browne SJ, Aebischer NJ, Moreby SJ, Teague L (2006) The diet and disease susceptibility of grey partridges Perdix perdix on arable farmland in East Anglia, England. Wildl Biol 12:3-10. https://doi. org/10.2981/0909-6396(2006)12[3:TDADSO]2.0.CO;2

Buckley K, Kelly P, Kavanagh B, O'Gorman EC, Carnus T, McMahon BJ (2012) Every partridge counts - successful techniques used in the captive conservation breeding programme for wild grey partridge in Ireland. Anim Biodivers Conserv 35:387-393

Buckley KP, Byrne ÉB, Sleeman DP (2015) Diet of Irish stoats (Mustela erminea hibernica) in two habitats. Ir Nat J 34:8-12

Buckley K, Wyse J, Mc Mahon BJ (2017) The conservation of the Hen Harrier Circus cyaneus in Ireland: opportunities in another landscape. In: Seventh Irish ornithological research conference. University College Cork, Ireland, p 7

Buner F, Schaub M (2008) How do different releasing techniques affect the survival of reintroduced grey partridges Perdix perdix? Wildl Biol 14:26-35. https://doi.org/10.2981/0909-6396(2008)14[26: HDDRTA]2.0.CO;2

Buner F, Browne S, Aebischer N (2011) Experimental assessment of release methods for the re-establishment of a red-listed galliform, the grey partridge (Perdix perdix). Biol Conserv 144:593-601. https://doi.org/10.1016/j.biocon.2010.10.017

Butler SJ, Boccaccio L, Gregory RD, Vorisek P, Norris K (2010) Quantifying the impact of land-use change to European farmland bird populations. Agric Ecosyst Environ 137:348-357. https://doi. org/10.1016/j.agee.2010.03.005

Carroll JP (1990) Winter and spring survival of radio-tagged gray partridge in North Dakota. J Wildl Manag 54:657-662. https://doi.org/ $10.2307 / 3809365$

Colhoun K, Cummins S (2013) Birds of conservation concern in Ireland. Ir Birds 9:523-544

Collier MJ, Scott MJ (2008) Industrially harvested peatlands and afteruse potential: understanding local stakeholder narratives and landscape preferences. Landsc Res 33:439-460. https://doi.org/10.1080/ 01426390801948406

Coombs F (1978) The crows: a study of the corvids of Europe. Batsford, London

Copland A, Marytn M, Buckley K (2009) Grey partridge agrienvironmental scheme. Submission to the department of agriculture for a pilot grey partridge agri-environmental measure in West Offaly. Unpublished submission to the Department of Agriculture, Fisheries, and Food

Craighead JJ, Craighead FC (1956) Hawks, owls, and wildlife. Stackpole \& Company, Harrisburg

Crofton D (1996) A profile of the NARGC and its concerns. NARGC Head Office, 6 Sandford Road, Ranelagh, Dublin 6, Ireland

Dahlgren JW (1987) Partridge activity, growth rate, and survival: dependence on insect abundance. Ph.D. Thesis. University of Lundgren, Sweden

Dahlgren JW (1990) The significance of arthropods in the gray partridge diet. In: Church KE, Warner RE, Brady SJ (eds) Perdix V: gray partridge and ring-necked pheasant workshop. Kansas Department of Wildlife and Parks, Emporia, pp 202-213 
De Leo GA, Focardi S, Gatto M, Cattadori IM (2004) The decline of the grey partridge in Europe: comparing demographies in traditional and modern agricultural landscapes. Ecol Model 177:313-335. https://doi.org/10.1016/j.ecolmodel.2003.11.017

Donald PF, Green RE, Heath MF (2001) Agricultural intensification and the collapse of Europe's farmland bird populations. Proc R Soc Lond B Biol Sci 268:25-29. https://doi.org/10.1098/rspb.2000.1325

Egan T (1995). Natural colonisation of an industrial peatland cutuaway area. Study of Turraun cutaway, County Offaly. Diploma in Field Ecology. University College Cork, Ireland.

Enck JW (1987) The effect of insect abundance on gray partridge chick survivorship in New York. In: Kimmel RO, Schulz JW, Mitchell GJ (eds) Proceedings of Perdix IV, gray partridge workshop. Minnesota Department of Natural Resources, Madelia, pp 3-15

Ewald J, Potts GR, Aebischer N (2012) Restoration of a wild grey partridge shoot: a major development in the Sussex study, UK. Anim Biodivers Conserv 35:363-369

Ewald JA, Wheatley CJ, Aebischer NJ, Moreby SJ, Duffield SJ, Crick HQ, Morecroft MB (2015) Influences of extreme weather, climate and pesticide use on invertebrates in cereal fields over 42 years. Glob Chang Biol 21:3931-3950. https://doi.org/10.1111/gcb.13026

Farrell C, Foss P (1999) A survey of the cutover \& cutaway bog habitats of the Irish Midlands. Irish Peatland Conservation Council, 119 Capel Street, Dublin 1, Ireland

Green RE (1984) The feeding ecology and survival of partridge chicks (Alectoris rufa and Perdix perdix) on arable farmland in East Anglia. J Appl Ecol 21:817-830. https://doi.org/10.2307/2405049

Hearshaw J (1996) The ecology of the grey partridge (Perdix perdix) in the Irish Midlands. M.Sc. Thesis. University College Dublin, Dublin

Heery S (2018) Birds in central Ireland. Sixth mid-Shannon bird report (2012-2016). Birdwatch Ireland, Crank House, Banagher, Co. Offaly, Ireland, p 32

Homberger B, Jenni L, Duplain J, Lanz M, Schaub M (2014) Food unpredictability in early life increases survival of captive grey partridges (Perdix perdix) after release into the wild. Biol Conserv 177: 134-141. https://doi.org/10.1016/j.biocon.2014.06.023

Huallacháin D, Copland A, Buckley K, McMahon B (2015) Opportunities within the revised EU common agricultural policy to address the decline of farmland birds: an Irish perspective. Diversity 7:307-317. https://doi.org/10.3390/d7030307

Humphreys GR (1937) A-list of Irish birds. Government Stationery Office, Dublin

Inger R, Gregory R, Duffy JP, Stott I, Voříšek P, Gaston KJ (2015) Common European birds are declining rapidly while less abundant species' numbers are rising. Ecol Lett 18:28-36. https://doi.org/10. 1111/ele. 12387

Jancke S (2008) Habitat mapping of the project site. Unpublished report to the national grey partridge conservation project. 6 Sandford Road Ranelagh, Dublin 6, Ireland

Jenkins D (1955) Causes of death in partridges. Bird Study 2:142-143. https://doi.org/10.1080/00063655509475823

Jenkins D (1961) Population control in protected partridges (Perdix perdix). J Anim Ecol 30:235-258. https://doi.org/10.2307/2296

Karanth KU, Nichols JD, Seidenstricker J, Dinerstein E, Smith JLD, McDougal C, Johnsingh AJT, Chundawat RS, Thapar V (2003) Science deficiency in conservation practice: the monitoring of tiger populations in India. Anim Conserv 6:141-146. https://doi.org/10. 1017/S1367943003003184

Kavanagh B (1990) Baseline ecological survey of Turraun Cutaway Bog, Co. Offaly, Report prepared for Bord Na Móna. Royal College of Surgeons, England

Kavanagh B (1992) Irish grey partridge (Perdix perdix) population survey 1991, with special reference to population and habitat use on cutaway bogland, in M. Birkan, G.R. Potts, N. J Aebischer \& S.D. Dowell (eds), Perdix V1: first symposium on partridges, quails, and francolins. Giber Faune Sauvage 9:503-504
Kavanagh B (1998) Can the Irish grey partridge (Perdix perdix) population be saved? A national conservation strategy for the future, in $\mathrm{M}$. Birkan, L.M. Smith, N.J. Aebischer, F.J. Purroy \& P.A. Robertson (eds.), Perdix VII: symposium on partridges, quails, and pheasants. Gibier Faune Sauvage, Game Wildl 15:533-546

Kavanagh B (2001) The re-introduction of the grey partridge (Perdix perdix) to Irish farmland: Towards a methodology. In Perdix V111, International symposium on partridges, quails and pheasants, eds. S.FARGO. Hungarian Small Game Bull 6:87-96

Keller V, Herrando S, Voříšek P, Franch M, Kipson M, Milanesi P, Martí D, Anton M, Klvaňová A, Kalyakin MV, Bauer H-G, Foppen RPB (2020) European Breeding Bird Atlas 2: distribution, abundance and change. European Bird Census Council \& Lynx Edicions, Barcelona, pp 84-85

Kennedy P, Ruttledge RF, Scroop CF (1954) The birds of Ireland. Oliver and Boyd Ltd., Edinburgh

Kirkwood TBL (1979) Geometric means and measures of dispersion. Biometrics 35:908-909

McCabe RA, Hawkins AS (1946) The Hungarian partridge in Wisconsin. Am Midl Nat 36:1-75. https://doi.org/10.2307/2421621

McMahon BJ, Helden A, Anderson A, Sheridan H, Kinsella A, Purvis G (2010) Interactions between livestock systems and biodiversity in South-East Ireland. Agric Ecosyst Environ 139:232-238. https:// doi.org/10.1016/j.agee.2010.08.008

McMahon BJ, Teeling EC, Höglund J (2014) How and why should we implement genomics into conservation? Evol Appl 7:999-1007. https://doi.org/10.1111/eva.12193

Meriggi A, Della, Stella RM (2004) The high mortality rate in the reintroduced grey partridge population in central Italy. Ital J Zool 69: $19-24$

Morgan DO, Clapham PA (1934) Some observations on gape-worm in poultry and game birds. J Helminthol 12:63-70. https://doi.org/10. 1017/S0022149X00003187

Newton I (1993) Predation and limitation of bird numbers. In: Power DM (ed) Current ornithology. Plenum Press, New York, NY, pp 159162

O'Donoghue BG (2010) The ecology of Hen Harriers (Circus cyaneus) in Ireland. $\mathrm{PhD}$ Thesis. University College Cork, Ireland

O'Gorman EC (2001) Home range and habitat use of the endangered grey partridge (Perdix perdix) in the Irish midlands. Ph.D. Thesis. Trinity College, Dublin, Ireland

Panek M (1992) The effect of environmental factors on survival of grey partridge (Perdix perdix) chicks in Poland during 1987-89. J Appl Ecol 29:745-750. https://doi.org/10.2307/2404484

Parish DMB, Sotherton NW (2007) The fate of released captive-reared grey partridges Perdix perdix: implications for reintroduction programmes. Wild Biol 13:140-149

Pépin D, Birkan M, Angibault J-M (2008) Factors affecting changes in grey partridge population dynamics in a French arable farmland over an eleven-year period. Eur J Wildl Res 54:179-187. https://doi.org/ $10.1007 / \mathrm{s} 10344-007-0125-\mathrm{z}$

Potts GR (1980) The effects of modern agriculture, nest predation and game management on the population ecology of partridges (Perdix perdix and Alectoris rufa). Adv Ecol Res 11:1-79. https://doi.org/ 10.1016/S0065-2504(08)60266-4

Potts GR (1986) The partridge, pesticides, predation, and conservation. Collins, London

Potts GR (2012) Partridges. Countryside barometer. New naturalist library book 121. Collins, London

Potts GR, Aebischer NJ (1995) Population dynamics of the grey partridge Perdix perdix 1793-1993: monitoring, modelling and management. IBIS 137:S29-S37. https://doi.org/10.1111/j.1474-919X.1995. tb08454.x

Preston CR (1990) Distrubution of raptor foraging in relation to prey biomass and habitat structure. Condor 92:107-112 
R Core Team (2017) R: a language and environment for statistical computing. R Foundation for Statistical Computing, Vienna, Austria

Rands MRW (1985) Pesticide use on cereals and the survival of grey partridge chicks: a field experiment. J Appl Ecol 22:49-54. https:// doi.org/10.2307/2403325

Rands MRW (1986a) Effect of hedgerow characteristics on partridge breeding densities. J Appl Ecol 23:479-487. https://doi.org/10. $2307 / 2404030$

Rands MRW (1986b) The survival of gamebird (Galliformes) chicks in relation to pesticide use on cereals. IBIS 128:57-64. https://doi.org/ 10.1111/j.1474-919X.1986.tb02092.x

Reitz F (1988) A model for estimating breeding success in the grey partridge (Perdix perdix L.) from weather conditions. Gibier Faune Sauvage 5:203-212

Rosin AV, Meriggi A, Pella F, Zaccaroni M (2010) Demographic parameters of reintroduced grey partridges in central Italy and the effect of weather. Eur J Wildl Res 56:369-375. https://doi.org/10.1007/ s10344-009-0329-5

Rymešová D, Tomášek O, Š́lek M (2013) Differences in mortality rates, dispersal distances and breeding success of commercially reared and wild grey partridges in the Czech agricultural landscape. Eur J Wildl Res 59:147-158. https://doi.org/10.1007/s10344-012-0659-6

Sharrock JTR (1976) The Atlas of breeding birds in Britain and Ireland. T. \& A. D. Poyser, Berhamstead
Sotherton NW (1991) Conservation headlands: a practical combination of intensive cereal farming and conservation. In: Firbank LG, Carter N, Darbyshire JF, Potts GR (eds) The ecology of temperate cereal fields. Blackwell Scientific Publications, Oxford, pp 193-197

Sotherton NW, Aebischer NJ, Ewald JA (2014) Research into action: grey partridge conservation as a case study. J Appl Ecol 51:1-5

Species trends Keller et al (2020) PECBMS. https://pecbms.info/trendsand-indicators/species-trends/species/perdix-perdix/. Accessed 4 Feb 2021

Tapper SC, Potts GR, Brockless MH (1996) The effect of an experimental reduction in predation pressure on the breeding success and population density of grey partridges Perdix perdix. J Appl Ecol 33: 965-978. https://doi.org/10.2307/2404678

Ussher RJ, Warren R (1900) The birds of Ireland. Gurney and Jackson, London

Watson D (1977) The Hen Harrier. Poyser, Berkhamsted

Westerskov K (1949) The recent decline of the Hungarian partridge. Ohio Conserv Bull 13:20-21

Whilde A (1993) Threatened mammals, birds, amphibians, and fish in Ireland. HMSO, Belfast

Yeatter RE (1934) The Hungarian partridge (Perdix perdix) in the Great Lakes region. Bull Sch For 5:1-92

Publisher's note Springer Nature remains neutral with regard to jurisdictional claims in published maps and institutional affiliations. 